\title{
Effect of unsaturated fatty acid supplementation on digestion, metabolism and nutrient balance in dairy cows during the transition period and early lactation
}

\author{
Francisco Palma Rennó ${ }^{1}$, José Esler de Freitas Júnior ${ }^{1}$, Jefferson Rodrigues Gandra', Milton \\ Maturana Filho ${ }^{1}$, Lenita Camargo Verdurico ${ }^{1}$, Luciana Navajás Rennó ${ }^{2}$, Rafael Villela Barletta ${ }^{1}$, \\ Flávio Garcia Vilela ${ }^{1}$
}

\footnotetext{
${ }^{1}$ Departamento de Nutrição e Produção Animal, Faculdade de Medicina Veterinária e Zootecnia, Universidade de São Paulo, Pirassununga, SP, Brasil. 2 Departamento de Zootecnia, Universidade Federal de Viçosa, Viçosa, MG, Brasil.
}

\begin{abstract}
The objective of this study was to evaluate the influence of unsaturated fatty acids in diets for dairy cows during the transition period and early lactation on intake, digestion and nutrient balance. Thirty-six multiparous and pregnant Holstein cows were randomly distributed to receive one of the experimental diets in the period from 35 days before the expected date of parturition to 84 days post-partum. Diets were fed as a total mixed ration and were as follows: control (C); soybean oil (SO), based on inclusion of $30 \mathrm{~g} / \mathrm{kg}$ (DM basis); and calcium salts of unsaturated fatty acids (CS), based on inclusion of $30 \mathrm{~g} / \mathrm{kg}$ (DM basis). Pre-partum dry matter intakes (DMI) of cows fed C, SO and CS were 11.9, 9.5 and $9.6 \mathrm{~kg} / \mathrm{d}$, respectively. Postpartum DMI was affected by experimental diets (18.5, 15.0 and $17.4 \mathrm{~kg} / \mathrm{d}$ for C, SO and CS, respectively). The energy balance in the transition period of animals fed CS was $4.41 \mathrm{Mcal} / \mathrm{d}$ higher than cows fed SO and $1.3 \mathrm{Mcal} / \mathrm{d}$ higher than cows fed C. Supplementing cows with unsaturated fatty acid sources is a strategy for dairy cows in the transition period.
\end{abstract}

Key Words: dry matter intake, energy balance, ruminant digestion

\section{Introduction}

The interest in nutrition and management of cows during the transition period has increased in recent years. The transition period is associated with increased risk of metabolic disorders due to large homeorhetic changes, caused mainly by altered hormonal profile (Ingvartsen et al., 2003; Friggens et al., 2004). Furthermore, these changes are commonly associated with the nutritional management during the dry period, metabolic status and reproductive and productive performance of the subsequent lactation. According to Bell (1995), the net energy requirements of lactation and metabolizable protein in healthy cows on the fourth day post-partum exceeds intake by 26 and $25 \%$, respectively.

The inclusion of additional sources of fat composed of long-chain fatty acids in diets for ruminants can bring benefits to the metabolic status during the transition period. This occurs because fatty acids are traditionally considered sources of energy and, recently, they have also played an important role influencing the physiology and metabolism of animals (Allen, 2000).

Received September 17, 2012 and accepted September 18, 2013

Corresponding author: joseeslerfjr@usp.br

http://dx.doi.org/10.1590/S1516-35982014000400008

Copyright (C) 2014 Sociedade Brasileira de Zootecnia. This is an Open Access article distributed under the terms of the Creative Commons Attribution Non-Commercial License, which permits unrestricted non-commercial use, distribution, and reproduction in any medium, provided the original work is properly cited.
However, the inclusion of additional sources of fat can cause changes in basal metabolism, especially the rumen metabolism, microbial flora, digestibility and nutrient utilization (Moallem, et al., 2007; Palmquist, 2007). Furthermore, research findings suggest that the negative response to fat supplementation is more variable when diets are based totally, or mainly, on corn silage as roughage (Jenkins and Bridges, 2007). According to Grum et al. (1996), dry cows fed fatty acid sources (palmitic and oleic acids) present increased significance in the ability of $\beta$-oxidation in liver fatty acids (LCFA) and lower concentration of triacylglycerols in the liver in the initial period of lactation. Other studies that evaluated supplemental fat sources containing LCFA have shown that such sources stimulated the liver capacity of $\beta$-oxidation of LCFA (Grum et al., 1996; Mashek et al., 2003). Longchain fatty acids have an important role on physiological functions and supply dietary energy, although several changes that occur in the physiological adaptation process during the transition period must be considered. There is little information in the current literature about the physiological adaptation process in the transition period and special attention is required for nitrogen metabolism, ruminal fermentation, volatile fatty acid profile, efficiency of microbial protein synthesis, energy metabolism and nutrient digestibility. 
Thus, the objective of this study was to evaluate the use of unsaturated fatty acids in diets for dairy cows during the transition period and early lactation on productive performance, nutrient digestion and nutrient balance.

\section{Material and Methods}

All experimental procedures applied in this research complied with the Ethical Principles in Animal Experimentation recommended by the Bioethics Committee of the Faculdade de Medicina Veterinária e Zootecnia of Universidade de São Paulo, protocol number 1051/2007.

Thirty-six multiparous and pregnant Holstein cows with 35 days before the expect date of parturition were evaluated during the pre-partum period $(660 \pm 66.9 \mathrm{~kg}$; mean $\pm \mathrm{SD})$, at calving, and at 84 days of lactation $(580 \pm 66.9 \mathrm{~kg}$; mean \pm SD).

Diets were formulated according to requirements of the NRC (2001), and animals were randomly assigned to receive the following experimental diets: Control (C); soybean oil (SO) based on inclusion of $30 \mathrm{~g} / \mathrm{kg}$ (DM basis); and calcium salts of unsaturated fatty acids (CS) (Megalac- $\mathrm{E}^{\circledR}$, Química Geral do Nordeste - QGN and Arm and Hammer, Inc.), based on inclusion of $30 \mathrm{~g} / \mathrm{kg}$ (DM basis).

Throughout the experiment, cows were housed in tie stalls and diets were fed as a total mixed ration (TMR) twice daily, at $08.00 \mathrm{~h}$ and at $13.00 \mathrm{~h}$. Amounts of feed offered and orts for each cow were weighted daily and restricted to 5 to $10 \%$ of intake on an as-fed basis.

Samples of all diet ingredients $(0.5 \mathrm{~kg})$ and orts samples (12.5\% of total daily orts) from each cow were collected daily and combined into one sample to represent the period of one week, and stored at $-20^{\circ} \mathrm{C}$ for subsequent laboratory analysis.

In the feed provided, samples of orts and feces were analyzed for dry matter (DM), organic matter (OM), mineral matter $(\mathrm{MM})$, ether extract (EE), crude protein (CP), neutral detergent insoluble nitrogen (NDIN), acid detergent insoluble nitrogen (ADIN) and lignin, according to the methods described by the Association of Official Analytical Chemists (AOAC, 2000) (Table 1). The total carbohydrates (TC) were calculated according to Sniffen et al. (1992): TC $=100-(\% \mathrm{CP}+\% \mathrm{EE}+\% \mathrm{MM})$. Non-fibrous carbohydrates (NFC) were estimated as recommended by Hall (1998), as follows: NFC $=100-[(\% \mathrm{CP}-\% \mathrm{CPurea}$ $+\%$ Urea) $+\% \mathrm{EE}+\% \mathrm{MM}+\% \mathrm{NDF}]$. The total digestible nutrients were calculated according to Weiss et al. (1992). The contents of neutral detergent fiber (NDF), ash- and protein-free neutral detergent fiber (NDFap) and acid detergent fiber (ADF) were obtained according to a method described by Van Soest et al. (1991), using $\alpha$-amylase and without addition of sodium sulfite in the NDF determination, with an Ankon ${ }^{\circledR}$ System.

To evaluate the fatty acid profile of experimental diets and ingredients (Table 2 and 3), the extraction process was performed according to Folch et al. (1957) and separated fat was methylated and the methyl esters were formed according to Kramer et al. (1997). Fatty acids were quantified by gas chromatography (GC Shimatzu 2010 with automatic injection) using a SP-2560 capillary column $(100 \mathrm{~m} \times 0.25 \mathrm{~mm}$ i.d. with $0.02-\mu \mathrm{m}$ film thickness; Supelco, Bellefonte, PA). Oven temperature was $70{ }^{\circ} \mathrm{C}$ for 4 minutes, then increased by $13{ }^{\circ} \mathrm{C}$ minute ${ }^{-1}$ to $175^{\circ} \mathrm{C}$, and held for 27 minutes. After, a further increase of $4{ }^{\circ} \mathrm{C}$ minute ${ }^{-1}$ was started until $215^{\circ} \mathrm{C}$, and kept for 31 minutes. Hydrogen $\left(\mathrm{H}_{2}\right)$ was used as carrier gas with a flow of $40 \mathrm{~cm}^{3} \mathrm{~s}^{-1}$. Four standards were used to identify the fatty acids that were formed during the biohydrogenation of unsaturated fatty acids: standard C4-C24 of fatty acids (Supelco ${ }^{\circledR}$ TM 37), vaccenic acid C18: 1 trans-11 (V038- 1G, Sigma ${ }^{\circledR}$ ), CLA C18: 2 trans-10, cis-12 (UC-61M $100 \mathrm{mg}$ ), CLA and C18: 2 cis-9, trans-11 (UC-60M 100 mg), (NU-CHEK-PREP USA ${ }^{\circledR}$ ).

For iADF concentration analysis, samples of feces ( -21 and -7 days pre-partum and $+14,+28$ and +56 days post-partum), feed and orts and were placed in non-woven textile bags (TNT; $100 \mathrm{~g} / \mathrm{m}^{2}$ ) with dimension $4 \times 5 \mathrm{~cm}$ (Casali et al., 2008). The aliquots were placed in all the bags, at $20 \mathrm{mg} / \mathrm{cm}^{2}$ of surface rate (Nocek, 1988). The samples were incubated in the rumen of cannulated dry cows receiving the same diet used in the digestion and metabolism trial for $288 \mathrm{~h}$ (12 days), to determine the iADF. Subsequently, fecal dry matter excretion was calculated to determine total apparent digestibility of dry matter and nutrients.

Energy values were calculated as follows: digestible energy $(\mathrm{DE})$ intake $=$ gross energy $(\mathrm{GE})$ intake $\times \mathrm{GE}$ digestibility (GE digestibility as reported in Harvatine and Allen, 2006); NEL intake was calculated from DE through ME, according to NRC (2001). Milk NEL (Mcal/d) $=$ milk yield $(\mathrm{kg}) \times[0.0929 \times($ Fat \% $)+0.0563 \times($ True protein \% $)$ $+0.0395 \times($ Lactose \%)] (NRC, 2001); NEL body weight gain was calculated according to the NRC (2001); and NEL available for maintenance $=$ NEL intake - NEL milk - NEL body weight gain.

Cows were mechanically milked twice daily, at $06.30 \mathrm{~h}$ and $15.30 \mathrm{~h}$, with milk production recorded daily during all the experimental period. Milk samples for analysis were collected at the same time of milkings weekly from parturition to 12 weeks of lactation.

The total nitrogen of the urine samples was determined according to methods described by the Association of 
Official Analytical Chemists (AOAC, 2000), where the amount in grams of nitrogen per $100 \mathrm{~mL}$ of urine (prepartum -21 and -7 days, and post-partum period $+14,+28$ and +56 days) was obtained by dividing the crude protein value of the samples by factor 6.25 for urine samples.
The concentrations of allantoin and uric acid in urine and milk were determined by the colorimetry method, according to the methodology described by Chen and Gomes (1992). Total excretion of purine derivatives, in $\mathrm{mmol} /$ day, for cows, was calculated as the sum of quantities

Table 1 - Ingredients and nutritional composition of the experimental diets during the pre- and post-partum periods

\begin{tabular}{|c|c|c|c|c|c|c|}
\hline \multirow{3}{*}{ Ingredients } & \multicolumn{6}{|c|}{ Experimental diets } \\
\hline & \multicolumn{3}{|c|}{ Pre-partum } & \multicolumn{3}{|c|}{ Post-partum } \\
\hline & $\mathrm{C}$ & $\mathrm{SO}$ & $\mathrm{CS}$ & $\mathrm{C}$ & $\mathrm{SO}$ & $\mathrm{CS}$ \\
\hline & \multicolumn{6}{|c|}{$\mathrm{g} / \mathrm{kg}$ of $\mathrm{DM}$} \\
\hline Corn silage $^{1}$ & 750.2 & 750.2 & 750.2 & 470.2 & 470.2 & 470.2 \\
\hline Ground corn & 133.8 & 103.2 & 103.2 & 272.8 & 249 & 253.1 \\
\hline Soybean meal & 94.7 & 94.6 & 94.6 & 221.3 & 213 & 213 \\
\hline Calcium salts of fatty acids & - & - & 29.9 & - & - & 33.1 \\
\hline Soybean oil & & 29.9 & - & - & 30.2 & - \\
\hline Urea & 9.7 & 10.5 & 10.5 & 3.9 & 5.8 & 5.8 \\
\hline Ammonium sulfate & 0.8 & 0.8 & 0.8 & 0.5 & 0.5 & 0.5 \\
\hline Sodium bicarbonate & - & - & - & 8.1 & 8.1 & 8.1 \\
\hline Magnesium oxide & - & - & - & 2.0 & 2.0 & 2.0 \\
\hline Dicalcium phosphate & 0.8 & 0.8 & 0.8 & 5.5 & 5.5 & 5.5 \\
\hline Limestone & 4.0 & 4.0 & 4.0 & 9.9 & 9.9 & 2.9 \\
\hline Mineral $^{2}$ & 2.8 & 2.8 & 2.8 & 2.6 & 2.6 & 2.6 \\
\hline Vitamins $^{3}$ & 1.6 & 1.6 & 1.6 & - & - & - \\
\hline Salt & 1.6 & 1.6 & 1.6 & 3.2 & 3.2 & 3.2 \\
\hline \multicolumn{7}{|l|}{ Nutrients $\mathrm{g} / \mathrm{kg}$ of DM } \\
\hline Dry matter & 475.4 & 478.1 & 474.5 & 618.0 & 619.4 & 615.3 \\
\hline Organic matter & 924.1 & 925.8 & 918.4 & 925.1 & 926.8 & 928.4 \\
\hline Crude protein & 156.8 & 151.2 & 151.2 & 187.9 & 186.8 & 187.2 \\
\hline Non-fiber carbohydrates & 407.8 & 377.8 & 386.2 & 456.6 & 417.9 & 419.5 \\
\hline $\mathrm{ADICP}^{4}$ & 152.3 & 151.2 & 151.2 & 114.8 & 118.3 & 118.5 \\
\hline $\mathrm{NDICP}^{4}$ & 162.2 & 164.5 & 161 & 163.3 & 162.8 & 162.9 \\
\hline Ether extract & 27.3 & 55.9 & 50.5 & 28.3 & 56.9 & 54.1 \\
\hline Neutral detergent fiber & 472.1 & 465.6 & 465.6 & 362.4 & 356 & 356.9 \\
\hline Acid detergent fiber & 298.2 & 295.4 & 295.4 & 212.1 & 210 & 210.2 \\
\hline Lignin & 45.2 & 44.2 & 44.7 & 34.8 & 33.7 & 33.7 \\
\hline Total carbohydrates & 737.6 & 712.4 & 717.7 & 694.7 & 662.8 & 665.1 \\
\hline Total digestible nutrients ${ }^{5}$ & 668.3 & 696.1 & 689.7 & 755.5 & 760.7 & 756.7 \\
\hline $\operatorname{NEL}(\mathrm{Mcal} / \mathrm{kg} \text { of DM})^{5}$ & 1.19 & 1.26 & 1.27 & 1.68 & 1.74 & 1.76 \\
\hline
\end{tabular}

C - control; SO - soybean oil; CS - calcium salts of fatty acids (Megalac-E ${ }^{\circledR}$ ).

${ }^{1}$ Corn silage contains: $34.44 \% \mathrm{DM}$ (natural matter) and $48.50 \% \mathrm{NDF} ; 7.50 \% \mathrm{CP} ; 10.07 \%$ mineral matter in dry matter, $1.47 \mathrm{NE} / \mathrm{kg}$ of DM.

${ }^{2}$ Composition per kg of product: Mg - 10 g; S - 9 g; Zn - 23,750 mg; Cu - 5,625 mg; Mn - 18,125 mg; Fe - 5,000 mg; Co - 125 mg; I - 312 mg; Se - 144 mg; F (Max.) 900 mg; vit. A - 2,000 IU; Vit E - 12,500 mg; Vit D - 5,000 IU.

${ }^{3}$ Composition per kg of product: vit. A - 8,000 IU; vit. E - 50,000 IU; vit. D - 2,300 IU.

${ }^{4}$ Percentage of total acid detergent insoluble crude protein (ADICP) and neutral detergent insoluble crude protein (NDCIP).

${ }^{5} \mathrm{NRC}(2001)$.

NEL - net energy for lactation.

Table 2 - Fatty-acid composition of experimental diets pre- and post-partum

\begin{tabular}{lcccccc}
\hline & \multicolumn{6}{c}{ Experimental diets } \\
\cline { 2 - 7 } Ingredients & \multicolumn{7}{c}{ Pre-partum } & \multicolumn{3}{c}{ Post-partum } \\
\cline { 2 - 7 } & $\mathrm{C}$ & $\mathrm{SO}$ & $\mathrm{CS}$ & $\mathrm{C}$ & $\mathrm{SO}$ & $\mathrm{CS}$ \\
\hline Fatty acids (g/100 g) & & & & & \\
C14:0 & 0.45 & 0.45 & 0.46 & 0.34 & 0.34 & 0.35 \\
C16:0 & 16.71 & 16.66 & 16.60 & 15.28 & 15.18 & 15.19 \\
C18:0 & 3.16 & 3.18 & 3.14 & 3.11 & 3.12 & 3.10 \\
C18:1 cis & 12.35 & 12.59 & 12.61 & 12.33 & 12.56 & 12.70 \\
C18:2 (n-6) & 26.97 & 27.12 & 26.95 & 32.86 & 32.92 & 33.04 \\
C18:3 (n-3) & 1.37 & 1.31 & 1.26 & 2.93 & 2.88 & 2.87 \\
Other & 3.69 & 3.68 & 3.84 & 2.74 & 2.71 & 2.88 \\
\hline C - & & &
\end{tabular}

$\mathrm{C}$ - control; SO - soybean oil; CS - calcium salts of fatty acids (Megalac-E ${ }^{\mathbb{R}}$ ).
Table 3 - Fatty-acid composition of ingredients

\begin{tabular}{lccccc}
\hline & \multicolumn{5}{c}{ Ingredients } \\
\cline { 2 - 6 } Ingredients & $\begin{array}{c}\text { Soybean } \\
\text { oil }\end{array}$ & CSFA & $\begin{array}{c}\text { Corn } \\
\text { ground }\end{array}$ & $\begin{array}{c}\text { Corn } \\
\text { silage }\end{array}$ & $\begin{array}{c}\text { Corn } \\
\text { silage }\end{array}$ \\
\hline Fatty acids $(\mathrm{g} / 100 \mathrm{~g})$ & & & & \\
C14:0 & 0.55 & 0.14 & 0.07 & 1.20 & 0.56 \\
C16:0 & 10.22 & 8.04 & 11.55 & 18.17 & 16.21 \\
C18:0 & 3.77 & 2.37 & 3.24 & 3.24 & 3.17 \\
C18:1 cis & 21.67 & 22.26 & 13.35 & 12.47 & 12.78 \\
C18:2 & 48.90 & 43.09 & 42.81 & 22.19 & 48.59 \\
C18:3 & 4.87 & 3.35 & 6.60 & - & 5.11 \\
Others & - & 5.21 & 0.42 & 4.58 & 2.11 \\
\hline
\end{tabular}

CSFA - calcium salts of fatty acids (Megalac-E $\left.{ }^{\circledR}\right)$. 
of allantoin and uric acid excreted in urine and milk (Orellana Boero, 2001).

In the evaluation of rumen fermentation, the samples of rumen fluid were collected with the use of esophageal gavage $3 \mathrm{~h}$ after the morning feeding. Immediately after collection, the rumen $\mathrm{pH}$ values were determined using a potentiometer. The samples were stored in a thermal box and sent for measurements of ammonia nitrogen $\left(\mathrm{NH}_{3}-\mathrm{N}\right)$ and short-chain fatty acids (acetic, propionic and butyric acids).

The collected rumen fluid was centrifuged at $2000 \times g$ for $15 \mathrm{~min}$, and $2 \mathrm{~mL}$ of the supernatant were pipetted and stored in test tubes containing $1 \mathrm{~mL}$ of $1 \mathrm{~N}$ sulfuric acid for later determination of ammonia nitrogen $\left(\mathrm{NH}_{3}-\mathrm{N}\right)$ concentration, and $1 \mathrm{~mL}$ in tubes containing $0.4 \mathrm{~mL}$ of formic acid to determine the short-chain fatty acids. The ammonia nitrogen $\left(\mathrm{NH}_{3}-\mathrm{N}\right)$ concentration was determined by the method with salicylic acid (Verdouw, 1973). The ruminal concentration of short-chain fatty acids was analyzed using gas chromatography and a $1 / 8^{\prime \prime}$ glass column of $2 \mathrm{~m}$ in length, packaged with $80 / 120$ Carbopack B-DA/4\% Carbowax 20M. The methodology used for analysis of volatile fatty acids was proposed by Erwin et al. (1961). Ammonia nitrogen $\left(\mathrm{N}-\mathrm{NH}_{3}\right)$ was determined by the salicylic acid method (Foldager, 1977).

The randomized experimental design used was based on expected date of parturition of the animals to compose the experimental groups. The collected data were analyzed using PROC MIXED of SAS software (Statistical Analysis System, version 9.2). The intake and total apparent digestibility of dry matter and nutrients, ruminal fermentation, microbial protein synthesis and energy and nitrogen balance were analyzed using effect of treatment (diet), time (weeks) and the interaction between time and treatment as fixed effects in the model, as follows:

$$
\mathrm{Y}_{\mathrm{ij}}=\mu+\mathrm{D}_{\mathrm{i}}+\mathrm{W}_{\mathrm{j}}+\mathrm{D}_{\mathrm{i}}\left(\mathrm{W}_{\mathrm{j}}\right)+\mathrm{e}_{\mathrm{ij}}
$$

in which: $\mu=$ mean, $D_{i}=$ fixed effect of diet; $W_{j}=$ fixed effect of week (weeks), $D_{i}\left(W_{j}\right)=$ week $\times$ diet interaction; and $\mathrm{e}_{\mathrm{ij}}=$ random error. The above model was used for analysis of pre-and post-partum, and the delivery time variable pre weeks $-4,-3,-2,-1$ weeks in relation to parturition and postpartum weeks 1 to 12 . The effect of animal was considered to be random.

In the analysis of weight, body condiction score measurements performed at 35 days pre-partum and were used as covariates in the model at $5 \%$ of probability preand postpartum, respectively.

The model was fitted by assuming four different variance-covariance structures: variance components or independent errors; compound symmetry with constant correlations among repeated measures; first-order auto- regressive correlations; and unstructured or unconstrained variance-covariance structure. The structures of variancecovariance were selected according to the Akaike information criterion. The best variance-covariance structure tested for this trial was AR(1), and it was used for all analyses.

To evaluate the effects of treatments, the following orthogonal contrasts were considered: $\mathrm{C} 1=$ control diet (C) versus soybean oil ( $\mathrm{SO}$ ), and calcium salts (CS); the objective was to compare the sources of fat with control diet regardless of the sources of long-chain fatty acids used; $\mathrm{C} 2$ = soybean oil diet versus calcium salts of fatty acids; the objective was to evaluate the differences between the sources of long chain fatty acids tested.

\section{Results}

No difference was detected for milk yield (MY) between cows supplemented or unsupplemented with unsaturated fatty acids (Table 4). However, milk fat concentration (3.3\%, 3.1\% and $2.8 \%$, for C, SO and CS, respectively) and body condition score (BCS) at post-partum were decreased with supplementation of unsaturated fatty acids.

Supplementation of unsaturated fatty acids had no effects on DM, OM, CP, and NDF in the pre-partum period (Table 5). However, inclusion of unsaturated fatty acids in diets of the pre-partum period increased ether extract intake $(\mathrm{P}=0.02)$ and decreased NFC intake $(\mathrm{P}=0.04)$.

In the post-partum period, cows fed $\mathrm{CS}$ and $\mathrm{SO}$ had lower intakes of DM $(\mathrm{P}=0.03 ; 16.23$ vs. $18.50 \mathrm{~kg} \mathrm{DM})$, OM $(\mathrm{P}=0.02), \mathrm{CP}(\mathrm{P}<0.01), \mathrm{NDF}(\mathrm{P}=0.01)$, and NFC $(\mathrm{P}<0.01)$ than cows fed $\mathrm{C}$ (Table 5). Furthermore, cows fed SO presented lower intakes of DM $(\mathrm{P}=0.4), \mathrm{OM}(0.03)$, $\mathrm{CP}(\mathrm{P}=0.04), \mathrm{NDF}(\mathrm{P}=0.04), \mathrm{NFC}(0.04)$ and ether extract $(\mathrm{P}=0.04)$ than cows fed $\mathrm{CS}(\mathrm{C} 2$, Table 5$)$.

Cows fed CS and SO had higher apparent total tract digestibility of DM ( $\mathrm{P}=0.01,0.73$ vs. $0.68 \mathrm{~kg} / \mathrm{kg}), \mathrm{CP}$ $(\mathrm{P}=0.01,0.72 v s .0 .66 \mathrm{~kg} / \mathrm{kg})$ and $\mathrm{EE}(\mathrm{P}=0.01,0.87 v s$. 0.77). However, no differences were observed in apparent total tract digestibility of dry matter and nutrients during the post-partum period (Table 5).

Cows fed CS and SO, in the pre-partum period, had higher $\mathrm{pH}$ values and propionic acid concentration $(\mathrm{mol} / \mathrm{mmol})$ in ruminal fluid than cows fed $\mathrm{C}$; in addition, cows fed SO presented higher concentration $(\mathrm{mol} / \mathrm{mmol})$ of propionic acid than cows fed CS (Table 6). However, no difference was observed in the short-chain fatty acids amounts (mM) in both contrasts. The proportion of acetic and propionic fatty acids was decreased with unsaturated fatty acid supplementation $(\mathrm{C} 1, \mathrm{P}=0.01)$; furthermore, cows fed $\mathrm{SO}$ 
had lower proportion of acetic and propionic fatty acids than cows fed CS. Unsaturated fatty acid supplementation had no effect on the concentrations of $\mathrm{N}_{-} \mathrm{NH}_{3}$ and total SCFA.

No differences were observed in the post-partum values of $\mathrm{pH}$ and $\mathrm{N}-\mathrm{NH}_{3}$. Concentrations ( $\mathrm{mol} / \mathrm{mmol}$ ) of propionic acid increased and concentrations $(\mathrm{mol} / \mathrm{mmol})$ of butyric acid decreased in cows fed SO and CS. Moreover, cows fed SO had higher concentration of propionic fatty acid and less concentration of butyric acid than cows fed CS. Unsaturated fatty acid sources did not influence the concentration of acetic acid (mol/mmol); however, difference between cows fed SO and CS was observed (59.9 vs. 64.3).

Amounts of acetic and butyric fatty acids in ruminal fluid decreased when cows were fed SO and CS. Furthermore, $\mathrm{C} 2 / \mathrm{C} 3$ and total SCFA also decreased with unsaturated fatty acid supplementation. The amount of propionic acid was higher in cows fed SO than cows fed $\mathrm{CS}$, and the $\mathrm{C} 2 / \mathrm{C} 3$ ratio decreased when cows were fed $\mathrm{SO}$ compared with cows fed CS (Table 6).

Table 4 - Milk yield and composition

\begin{tabular}{|c|c|c|c|c|c|c|c|c|c|}
\hline \multirow{2}{*}{ Item } & \multicolumn{3}{|c|}{ Treatments } & \multirow{2}{*}{ SEM } & \multicolumn{5}{|c|}{ P-value ${ }^{1}$} \\
\hline & $\mathrm{C}$ & $\mathrm{SO}$ & $\mathrm{CS}$ & & Diet & Week & Int & $\mathrm{C} 1$ & $\mathrm{C} 2$ \\
\hline Milk yield (kg/day) & 32.2 & 30.4 & 30.9 & 0.34 & 0.744 & $<0.001$ & 0.722 & 0.465 & 0.829 \\
\hline Fat $(\%)$ & 3.3 & 3.1 & 2.8 & 0.04 & 0.015 & $<0.001$ & 0.159 & 0.013 & 0.098 \\
\hline \multicolumn{10}{|c|}{ Body conndition score } \\
\hline Pre-partum & 2.9 & 3.0 & 2.9 & 0.03 & 0.944 & $<0.001$ & 0.436 & 0.771 & 0.867 \\
\hline Post-partum & 2.6 & 2.5 & 2.5 & 0.04 & 0.001 & 0.070 & 0.988 & $<0.001$ & 0.443 \\
\hline
\end{tabular}

C - control; SO - soybean oil; CS - calcium salts of fatty acids (Megalac-E ${ }^{\circledR}$ ); C1 - control diet vs soybean oil and calcium salts; C2 - soybean oil diet vs. calcium salts; SEM - standard error of the mean; Int - diet $\times$ week interaction.

${ }^{1}$ Probability value of multivariate analysis considering the fixed effects of diet, time and interaction of the two variables.

Table 5 - Effects of experimental diets on intake and total apparent digestibility of dry matter and nutrients in the pre- and post-partum periods

\begin{tabular}{|c|c|c|c|c|c|c|c|c|c|}
\hline \multirow{2}{*}{ Item } & \multicolumn{3}{|c|}{ Treatments } & \multirow{2}{*}{ SEM } & \multicolumn{5}{|c|}{ P-value ${ }^{1}$} \\
\hline & $\mathrm{C}$ & SO & $\mathrm{CS}$ & & Diet & Week & Int & $\mathrm{C} 1$ & $\mathrm{C} 2$ \\
\hline \multicolumn{10}{|l|}{ Intake (kg/day) } \\
\hline Dry matter & 11.1 & 9.5 & 9.6 & 0.24 & 0.152 & $<0.001$ & 0.809 & 0.074 & 0.868 \\
\hline Organic matter & 9.1 & 7.7 & 7.7 & 0.27 & 0.260 & $<0.001$ & 0.998 & 0.104 & 0.996 \\
\hline Crude protein & 1.19 & 0.97 & 1.01 & 0.03 & 0.174 & $<0.001$ & 0.998 & 0.071 & 0.695 \\
\hline Ether extract & 0.40 & 0.54 & 0.59 & 0.01 & 0.008 & 0.039 & 0.939 & 0.002 & 0.468 \\
\hline \multicolumn{10}{|l|}{ Post-partum } \\
\hline Dry matter & 18.5 & 15.0 & 17.4 & 0.22 & 0.018 & $<0.001$ & 0.647 & 0.032 & 0.049 \\
\hline Organic matter & 16.9 & 13.6 & 15.9 & 0.20 & 0.012 & $<0.001$ & 0.700 & 0.025 & 0.038 \\
\hline Crude protein & 3.04 & 2.36 & 2.76 & 0.03 & 0.003 & $<0.001$ & 0.911 & 0.005 & 0.040 \\
\hline Neutral detergent fiber & 5.66 & 4.35 & 5.18 & 0.07 & 0.008 & $<0.001$ & 0.543 & 0.013 & 0.040 \\
\hline Dry matter & 0.68 & 0.72 & 0.74 & 0.73 & 0.024 & 0.041 & 0.052 & 0.011 & 0.296 \\
\hline Organic matter & 0.69 & 0.73 & 0.73 & 0.77 & 0.224 & 0.164 & 0.551 & 0.086 & 0.969 \\
\hline Crude protein & 0.66 & 0.71 & 0.73 & 0.95 & 0.042 & 0.025 & 0.990 & 0.016 & 0.456 \\
\hline Neutral detergent fiber & 0.55 & 0.60 & 0.62 & 1.37 & 0.278 & 0.339 & 0.980 & 0.123 & 0.700 \\
\hline Non-fiber carbohydrates & 0.87 & 0.88 & 0.86 & 0.68 & 0.788 & 0.676 & 0.068 & 0.815 & 0.520 \\
\hline Ether extract & 0.77 & 0.89 & 0.85 & 1.35 & 0.011 & 0.260 & 0.589 & 0.004 & 0.340 \\
\hline \multicolumn{10}{|l|}{ Post-partum } \\
\hline Dry matter & 0.72 & 0.73 & 0.69 & 0.45 & 0.564 & 0.765 & 0.453 & 0.342 & 0.554 \\
\hline Organic matter & 0.75 & 0.75 & 0.74 & 0.54 & 0.541 & 0.347 & 0.718 & 0.882 & 0.276 \\
\hline Crude protein & 0.73 & 0.73 & 0.73 & 0.70 & 0.939 & 0.149 & 0.670 & 0.843 & 0.771 \\
\hline Neutral detergent fiber & 0.52 & 0.50 & 0.55 & 1.26 & 0.418 & 0.291 & 0.444 & 0.897 & 0.193 \\
\hline Non-fiber carbohydrates & 0.93 & 0.92 & 0.91 & 0.59 & 0.327 & 0.036 & 0.391 & 0.199 & 0.445 \\
\hline
\end{tabular}

C - control; SO - soybean oil; CS - calcium salts of fatty acids (Megalac- $\mathrm{E}^{\mathbb{R}}$ ); C1 - control diet vs soybean oil and calcium salts; C2 - soybean oil diet vs. calcium salts; SEM - standard error of the mean; Int - diet $\times$ week interaction.

${ }^{1}$ Probability value of multivariate analysis considering the fixed effects of diet, time and interaction of the two variables. 
Table 6 - Parameters of rumen fermentation for the experimental diets

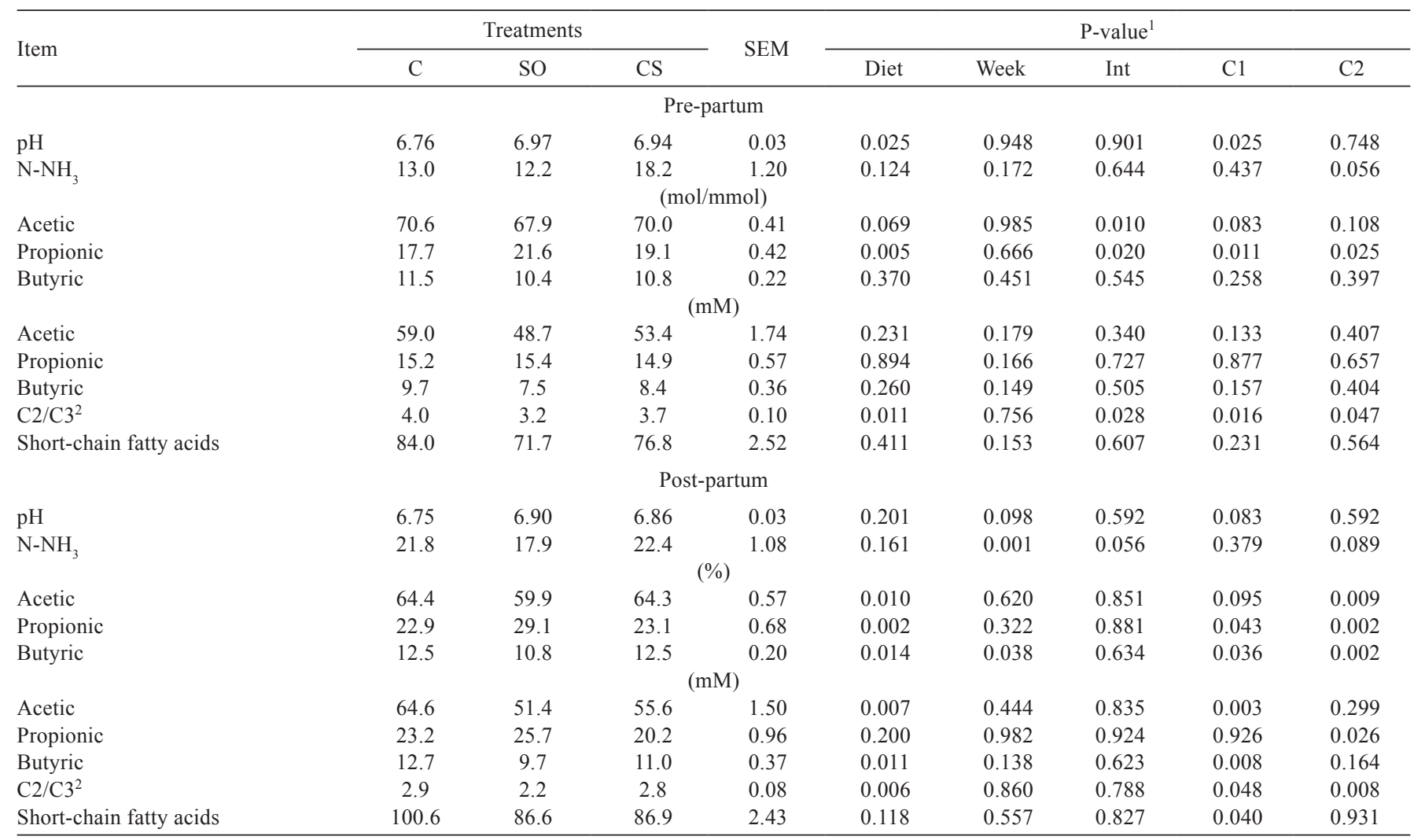

C - control; SO - soybean oil; CS - calcium salts of fatty acids (Megalac-E ${ }^{\circledR}$ ); C1 - control diet vs soybean oil and calcium salts; C2 - soybean oil diet vs. calcium salts; SEM - standard error of the mean; Int - diet $\times$ week interaction.

SCFA - short-chain fatty acids.

${ }^{1}$ Probability value of multivariate analysis considering the fixed effects of diet, time and interaction of the two variables.

${ }^{2}$ Acetic acid:propionic acid ratio.

Table 7 - Efficiency of microbial protein synthesis according to experimental diets in the pre- and post-partum periods

\begin{tabular}{|c|c|c|c|c|c|c|c|c|c|}
\hline \multirow{2}{*}{ Item } & \multicolumn{3}{|c|}{ Treatments } & \multirow{2}{*}{ SEM } & \multicolumn{5}{|c|}{ P-value ${ }^{1}$} \\
\hline & $\mathrm{C}$ & SO & $\mathrm{CS}$ & & Diet & Week & Int & $\mathrm{C} 1$ & $\mathrm{C} 2$ \\
\hline \multicolumn{10}{|c|}{ Pre-partum } \\
\hline Alla & 114.1 & 112.7 & 122.5 & 6.48 & 0.828 & 0.250 & 0.221 & 0.625 & 0.721 \\
\hline UAc & 15.8 & 14.2 & 18.5 & 1.13 & 0.579 & 0.593 & 0.899 & 0.754 & 0.321 \\
\hline PD & 124.1 & 120.2 & 126.0 & 7.15 & 0.952 & 0.223 & 0.422 & 0.800 & 0.863 \\
\hline UV (L/day) & 9.8 & 9.1 & 9.2 & 0.63 & 0.941 & 0.951 & 0.844 & 0.731 & 0.967 \\
\hline Alla: PD (g/100 g) & 91.1 & 93.5 & 88.8 & 0.81 & 0.117 & 0.215 & 0.676 & 0.918 & 0.040 \\
\hline Efficiency & 96.7 & 116.9 & 123.3 & 7.73 & 0.550 & 0.910 & 0.758 & 0.315 & 0.688 \\
\hline \multirow{2}{*}{\multicolumn{10}{|c|}{$\begin{array}{l}\text { Post-partum } \\
\text { (mmol/day) }\end{array}$}} \\
\hline & & & & & & & & & \\
\hline AbsP & 283.0 & 263.4 & 268.7 & 15.6 & 0.980 & 0.002 & 0.534 & 0.890 & 0.884 \\
\hline UV (L/day) & 16.4 & 15.2 & 16.5 & 0.82 & 0.643 & 0.159 & 0.664 & 0.568 & 0.444 \\
\hline Alla:PD (g/100 g) & 91.0 & 91.5 & 90.2 & 0.60 & 0.500 & 0.447 & 0.440 & 0.827 & 0.251 \\
\hline $\operatorname{micN}(g /$ day $)$ & 182.1 & 166.8 & 169.1 & 9.75 & 0.890 & 0.078 & 0.790 & 0.647 & 0.925 \\
\hline Efficiency & 120.5 & 133.1 & 118.5 & 9.29 & 0.868 & 0.626 & 0.737 & 0.943 & 0.621 \\
\hline
\end{tabular}

C - control; SO - soybean oil; CS - calcium salts of fatty acids (Megalac-E®); C1 - control diet vs soybean oil and calcium salts; C2 - soybean oil diet vs. calcium salts; SEM - standard error of the mean; Int - diet $\times$ week interaction.

Alla - daily excretion of allantoin; UAc - daily excretion of uric acid; PD - daily excretion of purine derivatives; AbsP - absorbed purines; micN - microbial nitrogen; UV - urinary volume; Alla/PD - allantoin/purine derivatives ratio.

${ }^{1}$ Probability value of multivariate analysis considering the fixed effects of diet, time and interaction of the two variables. 
The daily allantoin excretion:daily excretion of purine derivates ratio was higher $(\mathrm{P}=0.04)$ for cows fed $\mathrm{SO}$ than cows fed CS. Other parameters of microbial protein synthesis were not affected by unsaturated fatty acid supplementation pre- and post-partum (Table 7).

In the pre- and post-partum periods, effect of weeks was observed in all parameters. Interaction effect was only observed in net energy for gain (NEg). Cows did not present differences in all parameters of energy use efficiency and energy balance in the pre-partum period (Table 8).

In the post-partum period, intake of net energy for milk yield (NEL) did not change with unsaturated fatty acid supplementation; however, cows fed SO had lower NEL intake than cows fed CS. Change in empty body weight was higher for cow cows fed $\mathrm{C}$ than cows fed diets with unsaturated fatty acids. Energy balance and energy efficiency post-partum did not change with inclusion of unsaturated fatty acids; nevertheless cows fed CS had higher energy balance than cows fed SO. Energy efficiency also was not altered by unsaturated fatty acid supplementation, but cows fed CS had lower values (Table 8).

All parameters were influenced by week of lactation in the pre-partum period, and almost all parameters were affected by week of lactation in the post-partum period, except for urine nitrogen ( $\mathrm{g} /$ day). Interaction effect was observed for urine nitrogen $(\mathrm{g} / 100 \mathrm{~g})$ pre-partum (Table 9). The unsaturated fatty acid supplementation, in the prepartum period, decreased nitrogen intake (g/day), nitrogen balance (g/day), percentages of fecal nitrogen, urine nitrogen and nitrogen balance, and total fecal excretion (kg DM/day).

Table 8 - Effect of experimental diets on the efficiency of energy use and energy balance in the pre- and post-partum periods

\begin{tabular}{|c|c|c|c|c|c|c|c|c|c|}
\hline \multirow{2}{*}{ Item } & \multicolumn{3}{|c|}{ Treatments } & \multirow{2}{*}{ SEM } & \multicolumn{5}{|c|}{ P-value ${ }^{1}$} \\
\hline & $\mathrm{C}$ & $\mathrm{SO}$ & $\mathrm{CS}$ & & Diet & Week & Int & $\mathrm{C} 1$ & $\mathrm{C} 2$ \\
\hline \multicolumn{10}{|c|}{ Pre-partum } \\
\hline \multicolumn{10}{|l|}{ Intake } \\
\hline GE (Mcal/day) & 40.5 & 34.6 & 34.6 & 1.17 & 0.196 & $<0.001$ & 0.476 & 0.074 & 0.995 \\
\hline DE (Mcal/day) & 27.7 & 24.9 & 24.8 & 0.82 & 0.441 & $<0.001$ & 0.726 & 0.207 & 0.899 \\
\hline $\operatorname{NEL}(\mathrm{Mcal} / \text { day })^{2}$ & 18.5 & 17.7 & 18.6 & 0.54 & 0.866 & $<0.001$ & 0.058 & 0.801 & 0.640 \\
\hline NEm (Mcal/day) & 10.3 & 10.3 & 10.1 & 0.07 & 0.902 & $<0.001$ & 0.479 & 0.773 & 0.731 \\
\hline $\operatorname{NEg}(\mathrm{Mcal} / \mathrm{kg} / \text { day })^{3}$ & -1.19 & -1.99 & -1.48 & 0.34 & 0.061 & $<0.001$ & 0.003 & 0.064 & 0.127 \\
\hline \multicolumn{10}{|l|}{ Energy balance } \\
\hline $\mathrm{NE}(\mathrm{Mcal} / \text { day })^{4}$ & 5.38 & 5.50 & 6.19 & 0.57 & 0.925 & 0.006 & 0.647 & 0.810 & 0.759 \\
\hline \multicolumn{10}{|c|}{ Post-partum } \\
\hline \multicolumn{10}{|l|}{ Intake } \\
\hline GE (Mcal/day) & 74.8 & 62.6 & 74.4 & 0.93 & 0.047 & $<0.001$ & 0.774 & 0.102 & 0.056 \\
\hline DE (Mcal/day) & 55.1 & 47.0 & 53.6 & 0.74 & 0.124 & $<0.001$ & 0.945 & 0.183 & 0.115 \\
\hline $\operatorname{NEL}(\mathrm{Mcal} / \text { day })^{2}$ & 37.5 & 35.6 & 40.9 & 0.47 & 0.109 & $<0.001$ & 0.758 & 0.736 & 0.039 \\
\hline NEm (Mcal/day) & 9.48 & 9.45 & 9.42 & 0.04 & 0.989 & $<0.001$ & 0.916 & 0.897 & 0.950 \\
\hline \multicolumn{10}{|l|}{ Production } \\
\hline NEL (Mcal/day) ${ }^{5}$ & 21.2 & 19.3 & 18.7 & 0.20 & 0.167 & 0.002 & 0.171 & 0.067 & 0.656 \\
\hline CEBW (kg/day) & -0.66 & -0.65 & -0.35 & 0.05 & 0.055 & $<0.001$ & 0.792 & 0.017 & 0.934 \\
\hline NEg (Mcal/day) & -0.84 & -1.25 & -1.36 & 0.11 & 0.169 & $<0.001$ & 0.845 & 0.067 & 0.694 \\
\hline CBCS (Unit/day) & -0.02 & -0.01 & -0.02 & 0.01 & 0.794 & 0.166 & 0.947 & 0.658 & 0.610 \\
\hline \multicolumn{10}{|l|}{ Energy balance } \\
\hline NE (Mcal/day) ${ }^{4}$ & -0.29 & -4.15 & -0.99 & 0.37 & 0.055 & $<0.001$ & 0.810 & 0.178 & 0.002 \\
\hline $\operatorname{NETP}(\mathrm{Mcal} / \text { day })^{6}$ & -6.84 & -9.95 & -5.54 & 0.62 & 0.125 & $<0.001$ & 0.472 & 0.631 & 0.047 \\
\hline \multicolumn{10}{|l|}{ Energy efficiency } \\
\hline NEL milk/DEI ${ }^{7}$ & 0.41 & 0.439 & 0.36 & 0.01 & 0.033 & $<0.001$ & 0.496 & 0.651 & 0.011 \\
\hline NEL lactation/DEI ${ }^{8}$ & 0.39 & 0.40 & 0.35 & 0.01 & 0.043 & $<0.001$ & 0.487 & 0.315 & 0.010 \\
\hline
\end{tabular}

C - control; SO - soybean oil; CS - calcium salts of fatty acids (Megalac-E ${ }^{\circledR}$ ); C1 - control diet vs soybean oil and calcium salts; C2 - soybean oil diet vs. calcium salts SEM - standard error of the mean; Int - diet $\times$ week interaction.

GE - gross energy; DE - digestible energy; NEL - net energy for lactation; CEBW - change in empty body weight; NEm - net energy for maintenance; NEg - net energy for gain according to variation of body weight; CBCS - change in body condition score; NETP - net energy for the transition period; DEI - digestible energy intake.

${ }^{1}$ Probability value of multivariate analysis considering the fixed effects of diets, time and interaction of the two variables.

${ }^{2} \mathrm{NEL}($ intake $)=0.703 \times \mathrm{ME}($ intake $)-0.19+\{[(0.097 \times \mathrm{ME}($ intake $)+0.19) / 97] \times[\mathrm{EE}-3]\} ; \mathrm{ME}($ intake $)=1.01 \times(\mathrm{DE}($ intake $\left.))-0.45\right]+0.0046 \times(\mathrm{EE}-3)(\mathrm{NRC}, 2001)$.

${ }^{3}$ Calculated by the formulas of the NRC (2001).

${ }^{4} \mathrm{NE}=\mathrm{NE}($ intake $)-\mathrm{NE}($ gain BW $)-\mathrm{NE}($ milk $)-\mathrm{NE}$ (gestation).

${ }^{5} \mathrm{NE}$ for milk yield $(\mathrm{Mcal} / \mathrm{day})=$ milk yield $(\mathrm{kg}) \times(0.0929 \times$ Fat $\%+0.0563 \times$ true protein $\%+0.0395 \times 1$ lactose $\%)(\mathrm{NRC}, 2001)$.

${ }^{6} \mathrm{NE}=\mathrm{NE}$ (intake) $-\mathrm{NE}$ (gain BW) $-\mathrm{NE}($ milk) $-\mathrm{NE}$ (gestation) for the transition period (TP) 21 days post-partum.

${ }^{7}$ Efficiency milk $=(\mathrm{milk} / \mathrm{DEI})$

${ }^{8}$ Efficiency lactation $=(\mathrm{NE}$ milk yield $+\mathrm{NE}$ gain of $\mathrm{BW} / \mathrm{DEI})$ 
Table 9 - Nitrogen balance and nitrogen use efficiency according to experimental diets in the pre- and post-partum periods

\begin{tabular}{|c|c|c|c|c|c|c|c|c|c|}
\hline \multirow{2}{*}{ Item } & \multicolumn{3}{|c|}{ Treatments } & \multirow{2}{*}{ SEM } & \multicolumn{5}{|c|}{ P-value ${ }^{1}$} \\
\hline & $\mathrm{C}$ & SO & $\mathrm{CS}$ & & Diet & Week & Int & $\mathrm{C} 1$ & $\mathrm{C} 2$ \\
\hline \multicolumn{10}{|c|}{ Pre-partum } \\
\hline \multicolumn{10}{|l|}{ g/day } \\
\hline $\mathrm{N}$ intake & 256.9 & 206. & 208.8 & 7.32 & 0.056 & $<0.001$ & 0.555 & 0.017 & 0.925 \\
\hline Fecal N & 61.2 & 52.5 & 46.2 & 2.21 & 0.158 & $<0.001$ & 0.167 & 0.079 & 0.440 \\
\hline Urine $\mathrm{N}$ & 73.7 & 92.6 & 100.3 & 6.79 & 0.169 & $<0.001$ & 0.083 & 0.074 & 0.558 \\
\hline Fecal N & 24.5 & 27.4 & 22.8 & 1.46 & 0.479 & 0.046 & 0.431 & 0.861 & 0.234 \\
\hline Urine $\mathrm{N}$ & 42.5 & 75.2 & 62.8 & 6.91 & 0.009 & $<0.001$ & 0.001 & 0.004 & 0.246 \\
\hline $\mathrm{N}$ balance & 45.6 & 46.9 & 35.2 & 3.36 & 0.075 & $<0.001$ & 0.953 & 0.050 & 0.267 \\
\hline Total fecal excretion (kg DM/day) & 3.1 & 2.4 & 2.3 & 0.11 & 0.102 & $<0.001$ & 0.509 & 0.035 & 0.784 \\
\hline \multicolumn{10}{|c|}{ Post-partum } \\
\hline Milk N & 140.8 & 130.9 & 132.7 & 2.09 & 0.685 & 0.053 & 0.910 & 0.396 & 0.878 \\
\hline $\mathrm{N}$ balance & 123.0 & 85.9 & 106.2 & 5.20 & 0.344 & $<0.001$ & 0.222 & 0.223 & 0.432 \\
\hline \multicolumn{10}{|l|}{$\%$ of total $\mathrm{N}(\mathrm{g} / 100 \mathrm{~g})$} \\
\hline Fecal N & 24.1 & 24.4 & 23.9 & 0.45 & 0.965 & 0.110 & 0.449 & 0.982 & 0.794 \\
\hline Urine $\mathrm{N}$ & 30.8 & 31.1 & 30.9 & 1.38 & 0.968 & $<0.001$ & 0.239 & 0.887 & 0.835 \\
\hline Milk N & 27.4 & 32.9 & 27.5 & 0.45 & 0.145 & $<0.001$ & 0.691 & 0.289 & 0.095 \\
\hline $\mathrm{N}$ balance & 17.9 & 17.8 & 18.6 & 1.09 & 0.963 & $<0.001$ & 0.446 & 0.974 & 0.789 \\
\hline Efficiency $^{2}$ & 0.27 & 0.32 & 0.27 & 0.01 & 0.061 & $<0.001$ & 0.566 & 0.205 & 0.043 \\
\hline Total fecal excretion (kg DM/day) & 4.8 & 3.7 & 4.5 & 0.07 & 0.012 & $<0.001$ & 0.921 & 0.026 & 0.035 \\
\hline
\end{tabular}

C - control; SO - soybean oil; CS - calcium salts of fatty acids (Megalac-E $\mathrm{E}^{\circledR}$ ); $\mathrm{C} 1$ - control diet vs soybean oil and calcium salts; C2 - soybean oil diet vs. calcium salts; SEM - standard error of the mean; Int - diet $\times$ week interaction.

${ }^{1}$ Probability value of multivariate analysis considering the fixed effects of diets, time and interaction of the two variables.

${ }^{2}$ Milk yield in $\mathrm{kg} / \mathrm{kg}$ of nitrogen consumed.

In the post-partum period, higher nitrogen intake ( $\mathrm{g} /$ day) and total fecal excretion $(\mathrm{kg} / \mathrm{DM} / \mathrm{day})$ were observed for cows fed $\mathrm{C}$ than cows fed SO and CS; additionally, cows fed SO had lower nitrogen intake (g/day) than cows fed CS. Fecal nitrogen did not change with addition of unsaturated fatty acids; however, cows fed CS presented higher values of fecal nitrogen than cows fed SO. Cows fed $\mathrm{C}$ had higher total fecal excretion ( $\mathrm{kg} \mathrm{DM}$ /day) than cows fed $\mathrm{SO}$ and CS, and cows fed CS presented higher total fecal excretion than cows fed SO (Table 9).

\section{Discussion}

The $15 \%$ decrease in the milk fat content in the CS treatment was probably not sufficient to support the changes in milk and milk components needed for detection. The data from all animals used in this experiment also demonstrated no significant change in milk composition. The physiological process indicates that the diets containing additional fatty acid sources suffered incomplete rumen biohydrogenation, which could have caused reduction in the $\Delta^{9}$ desaturase enzyme activity, modifying the milk fat concentrations in cows fed CS (Table 4). Thus, the concentrations of CLA C18:2 cis-9, trans-11 in milk from cows fed calcium salts originate from two sources: ruminal biohydrogenation of polyunsaturated fatty acids and from endogenous synthesis, via $\Delta 9$ desaturase enzyme from FA trans-11-18:1 (Corl et al., 2001; Piperova et al., 2002). Rabiee et al. (2012), in a meta-analysis of 200 papers, found that the inclusion of fat in the diets for dairy cows had marked effects on milk, milk fat, production, DMI, and fat and protein contents in milk. According to these authors, the effect of the lower DMI combined with higher milk fat production showed that fats could improve the efficiency of milk production.

The increases in ether extract concentration in diets SO and CS explained the increases in the intake of this nutrient. The influence of unsaturated fatty acids and weeks on nutrient intake pre-partum can be attributed to reduction in DMI 21 days before partum and endocrine and metabolic changes (Bell, 1995; Allen, 2000).

The causes of DMI variations in pre-partum periods are not known, but may be related to the metabolic status of the animal. According to Grummer (1995), the reduction in DMI and its intensity pre-partum may be related to several factors including body condition and the effect of diet. 
Possibly, the trend of reduction in DMI for diets CS and SO can be attributed to the effect of supplementation and energy density of diets with fat sources, which led animals to have faster metabolic satiety in relation to the control group.

In this study, the sources of fatty acids affected the total apparent digestibility of dry matter and nutrients. According to Jenkins (1993) the decrease in the digestibility of DM and NDF in animals fed the SO and CS diets can be explained by decrease in the passage rate, and consequently the reduction in DMI and energy intake. The decrease in feed passage rate increased the retention time in the rumen, which consequently increased the digestibility of DM and nutrients (Van Soest, 1994). This behavior was observed for the DMI of cows in the pre-partum period, when cows were subjected to the SO and CS diets, compared with diet C (9.82 and 9.70 vs. $11.19 \mathrm{~kg} /$ day) (Table 5). The effect of the use of fatty acids on digestibility of nutrients can be influenced by the characteristics inherent to the fatty acid supplement used such as the saturation level of fatty acids and type of forage used during supplementation. According to Ben Salem et al. (1993), oils reduce the digestibility of TC when corn silage is provided as forage, compared with other forages such as grass hay. However, Bateman and Jenkins (1998) demonstrated that large quantities of soybean oil in combination with high amounts of forage in diets for dry cows can be provided without impairing the total apparent digestibility.

There were effects of diet on fiber digestibility and dry matter digestibility (Table 5). These data contradict the hypothesis that highly unsaturated fat sources like vegetable oils and calcium salts of fatty acids reduce the digestibility of nutrients, especially fiber. Extensive research has been conducted to determine the effects of supplemental fats on milk yield and composition, intake, and digestion. The decrease is related not only to quantity, but mainly to the type of fatty acid present in the supplement, given that lipids rich in unsaturated fatty acids tend to cause greater depression in digestibility (Doreau and Chilliard, 1997).

When evaluating the effect of ruminal inert fat sources as calcium salts of long-chain fatty acids on total apparent digestibility in relation to other fat sources, the results show that there may be benefits to the digestibility of nutrients for this type of fat source (Onetti and Grummer, 2004; Bateman and Jenkins, 1998). This occurs possibly because of the advantages of this supplement regarded as a fat source inert in rumen. According to Jenkins et al. (2008), there are some theories that justify a reduction of NDF digestibility with the use of unsaturated fat. However, evaluating studies in the literature that used calcium salts of fatty acids in diets for dairy cows, no decrease is observed in nutrient digestibility due to the low effect of fatty acids complexed with calcium (Onetti and Grummer 2004).

The greater $\mathrm{pH}$ values in the pre-partum period observed for the fat sources can be attributed, according to Jenkins et al. (2008) and Palmquist (2007), to large quantities of free unsaturated fatty acids in the rumen. These compounds enable the intensification of the ruminal biohydrogenation process, thereby promoting greater efficiency of utilization of free $\mathrm{H}+$, increasing the $\mathrm{pH}$ values in the rumen. However, despite the increase in the $\mathrm{pH}$ value attributed to the use of $\mathrm{H}+$ ions in the biohydrogenation process, Czerkawski, (1984) emphasized that only 1 to $2 \%$ the metabolic hydrogen is used for saturation of the unsaturated fatty acids.

Chen and Russell (1989) affirmed that the reduction of $\mathrm{NH}_{3}-\mathrm{N}$ concentration may be related to the depression effect of unsaturated lipids on the population of grampositive bacteria, notably the amino acid-fermenting mandatory group, to supply their energy and protein requirements. Changes in the percentage and proportion of VFA observed in animals supplemented with fat sources can be characterized as typical changes commonly observed when fat supplementation is used in diets for dairy cows (Jenkins and Bridges, 2007).

This occurs because the rumen digestion of structural carbohydrates at $0.50 \mathrm{~g} / \mathrm{g}$ of DM is impaired when less than $100 \mathrm{~g} / \mathrm{kg}$ of DM of fat is added to the diets for dairy cows.

This result is directly related to the protein metabolism in the rumen. The effect of fatty acids on ruminal degradability of nutrients can be minimized if the diet contains high amounts of roughage, which can be proven mainly by the capacity of the forage to maintain the normal functioning of the rumen. Thus, the effects of unsaturated fatty acids on the rumen digestion can be variable, so the kind of roughage used during supplementation can be considered a preponderant factor for that to occur (Ueda et al., 2003; Huang et al., 2008).

No effect of experimental diets on the excretion of purine derivatives and efficiency of microbial protein synthesis were observed pre- or postpartum (Table 6). However, the week of lactation affected the total daily excretion of urine, daily allantoin excretion, uric acid, allantoin in milk, total purine derivatives, and purine absorbed for animals in the postpartum period (Table 7 ).

The rumen microbial growth can be attributed mainly to increased DMI as a function of weeks of lactation, providing more energy and nitrogen and higher amounts of substrate for microbial protein synthesis in the rumen (NRC, 2001). 
As a consequence, excretion of purine derivatives in urine and milk (allantoin and uric acid) increased according to lactation weeks (Table 7).

Regardless of the diet used, the optimization of the rumen environment in early lactation can be changed with fat supplementation, although it increases the supply of substrate for microbial protein synthesis (MPS) (Allen, 2000). According to Palmquist et al. (1993) and Van Soest (1994), microbial efficiency as a consequence of the use of fat may be compromised by reducing the amount of rapidly fermentable carbohydrates, thereby reducing the amount of substrate available for the MPS. However, some studies observed in the literature have shown different results with the use of supplemental fat in diets for dairy cows. In 12 studies that evaluated fat supplementation and effects on the MPS, the fat sources did not reduce the efficiency of microbial protein synthesis and in some cases promoted its increase, and five of these studies used long-chain fatty acids (Doreau et al., 1993; Gozho et al., 2008).

Theoretically, the main advantage of CSFA and oil seeds is providing essential fatty acids that can go from the rumen to the abomasum intact. This hypothesis would result in the affirmation that fat would have little or no influence on the microbial population, preventing possible detrimental effects on ruminal degradation and absorption of nutrients (Table 7) (Palmquist and Mattos, 2006). However, it is necessary to emphasize that there are no studies on the MPS in dairy cows in the transition period.

The net energy balance (NEB) was more intense in the first week post-partum (approximately12.0 Mcal/day) and usually the EB of the animals came to be positive around the sixth week post-partum, corroborating the results usually observed in research studies on dairy cows. The effect of lactation week on the intakes of GE, DE, NEL, NEm and NEg, the energy balance and energy use efficiency can be attributed to the oscillations in the energy requirements of cows along the pre- and post-partum period evaluated, which are dependent on physiological changes to which the animals are subjected during the production cycle, in addition to the changes in consumption characteristics of these periods (Drackley, 1999; Zheng et al., 2005) (Table 8).

According to Quigley and Drewry (1998), the increased requirements of NEg in the pre-partum period of dairy cows can be justified by the variation in energy requirements of pregnant cows from 1.3 to 1.5 times the maintenance requirements at the end of gestation, besides the fact that the growth of fetal tissues becomes exponential in the third trimester of pregnancy (Bell, 1995).
The energy balance of fatty sources was less intense in the transition period when compared with diet C. Van Knegsel et al. (2007) observed better EB for cows fed lipogenic diets during the transition period, and this effect was associated with the reduction of nutrient partitioning for milk fat and body fat mobilization. After parturition, the EB of high-yield cows ( 35 to $40 \mathrm{~kg} /$ day) goes back to being positive at about the seventh week of lactation (Overton et al., 1999; Butler, 2004). Evidence demonstrates that supplemental fat can increase the NEFA concentration in the blood. Furthermore, Overton et al. (1999) emphasize that fat supplementation in early lactation can reduce the loss of body weight or BCS of cows. This theory was affirmed by Skaar et al. (1989), who reported that fat supplementation in diets for dairy cows accelerates weight gain after the animals start to have positive EB.

The effect of lactation week on the TNI in $\mathrm{g}$ /day, fecal $\mathrm{N}$ and urine $\mathrm{N}$ in $\mathrm{g} /$ day and percentage of TN, TFE and NB in the pre- and post-partum periods may be attributed to the decrease in DMI in the pre-partum period, a result of decreased ruminal space, as a function of the fetal growth, and of metabolic and hormonal changes that result in decreased intake (Bell, 1995; Drackley, 1999).

Onetti and Grummer (2004) evaluated the nitrogen balance of dairy cows at different stages of lactation, and also observed a reduction of the total nitrogen intake in early lactation. The higher intake values of TN and TFE in the pre- and post-partum periods for animals fed diet $\mathrm{C}$ compared with animals subjected to diets CS and SO occurred consistently. The higher efficiency of $\mathrm{N}$ utilization for animals fed the SO diet compared with diet CS can be attributed to absence of difference in performance and to the lower crude protein intake for diet SO in the pre- and postpartum periods (Table 5). Furthermore, there were small increases, though numerical, in the efficiency of MPS for diet SO compared with diets $\mathrm{C}$ and CS post-partum (133.13 versus 120.59 and 118.50), which explains the higher use of nitrogen for microbial growth, thus avoiding losses of $\mathrm{N}$ via urine and feces (Table 9).

Some studies conducted to evaluate the use of $\mathrm{N}$ in animals supplemented with fat did not reveal changes in nitrogen balance (Gozho et al., 2008; Petit, 2002). The observed differences in nitrogen intake ( $\mathrm{g} /$ day) between the experimental diets in the postpartum period followed the results of DMI (Table 5).

Thus, the protein metabolism of the animals was slightly modified with the fat sources, more specifically with SO, although the animals fed diet CS also showed variations in the rumen concentrations of $\mathrm{NH}_{3}-\mathrm{N}$ (Table 5). 


\section{Conclusions}

Unsaturated fatty acids have positive effects on energy balance in cows at early lactation. The use of calcium salts in diets for dairy cows during the transition period improves the metabolic balance without changing rumen fermentation, nitrogen metabolism or productive performance.

\section{References}

Allen, M. S. 2000. Effects of diet on short-term regulation of feed intake by lactating dairy cattle. Journal of Dairy Science $83: 1598-1624$

AOAC - Association of Official Analytical Chemists. 2000. Official methods of analysis. 17th ed. Washington, D.C.

Bateman, H. G. and Jenkins, C. 1998. Influence of soybean oil in high fiber diets fed to non lactating cows on ruminal unsaturated fatty acids and nutrient digestibility. Journal of Dairy Science 81:2451-2458.

Bell, A. W. 1995. Regulation of organic nutrient metabolism during transition from late pregnancy to early lactation. Journal of Animal Science 73:2804-2819.

Ben Salem, H.; Krzeminski, R.; Ferlay, A. and Doreau, M. 1993. Effect of lipid supply on in vivo digestion in cows: comparison of hayand corn-silage diets. Canada Journal Animal Science 73:547-557.

Butler, W. R. 2004. Effect of negative energy balance in the fertility of dairy cows. p.101-111. In: Proceedings of the 7th Progress of New Approaches in Production and Breeding of Cattle, Uberlândia.

Casali, A. O.; Detmann, E.; Valadares Filho, S. C.; Pereira, J. C.; Henriques, L. T.; Freitas, S. G. and Paulino, M. F. 2008. Influência do tempo de incubação e do tamanho de partículas sobre os teores de compostos indigestíveis em alimentos e fezes bovinas obtidos por procedimentos in situ. Revista Brasileira Zootecnia $37: 335-342$

Chen, G. and Russell, J. B. 1989. More monensin-sensitive, ammoniaproducing bacteria from the rumen. Applied and Environmental Microbiology 55:1052-1057.

Chen, X. B. and Gomes, M. J. 1992. Estimation of microbial protein supply to sheep and cattle based on urinary excretion of purine derivatives - an overview of technical details. Rowett Research Institute; International Feed Resources Unit, Bucksburnd, Aberdeen.

Corl, B. A.; Baumgard, L. H.; Dwyer, D. A.; Griinari, J. M.; Phillips, B. S. and Bauman, D. E. 2001. The role of $\Delta 9$-desaturase in the production of cis-9, trans-11 CLA. Journal of Nutritional Biochemistry 12:622-630.

Czerkawski, J. W. 1984. Microbial fermentation in the rumen. Proceedings Nutrition Society 43:101-180.

Doreau, M. and Chilliard, Y. 1997. Digestion and metabolism of dietary fat in farm animals. British Journal of Nutrition 78:15-35.

Doreau, M.; Ferlay, A. and Elmeddah, Y. 1993. Organic matter and nitrogen digestion by dairy cows fed calcium salts of rapeseed oil fatty acids or rapeseed oil. Journal of Animal Science 71:499-504.

Drackley, J. K. 1999. Biology of dairy cows during the transition period: The final frontier, Journal of Dairy Science 82:2259-2273.

Erwin, E. S.; Marco, G. J. and Emery, E. M. 1961. Volatile fatty acid analyses of blood and rumen fluid by gas chromatography. Journal of Dairy Science 44:1768-1777.

Folch, J.; Lees, M. and Stanley, G. H. S. 1957. A simple method for the isolation and purification of total lipids from animal tissues, Journal of Biological Chemistry 226:497-509.
Foldager, J. 1977. Protein requirement and non protein nitrogen for high producing cow in early lactation. Thesis (Ph.D.). Michigan State University, East Lasing.

Friggens, N. C.; Ingvartsen, K. L. and Emmans, G. C. 2004. Prediction of body lipid change in pregnancy and lactation. Journal of Dairy Science 87:988-1000.

Gozho, G. N. and Mutsvangwa, T. 2008. Influence of carbohydrate source on ruminal fermentation characteristics, performance, and microbial protein synthesis in dairy cows. Journal of Dairy Science 91:2726-2735.

Grum, D. E.; Drackley, J. K.; Younker, R. S.; Lacount, D. W. and Veenhuizen, J. J. 1996. Nutrition during the dry period and hepatic lipid metabolism of periparturient dairy cows. Journal of Dairy Science 79:1850-1864.

Grummer, R. R. 1995. Impact of changes in organic nutrient metabolism on feeding the transition dairy cow. Journal Animal Science 73:2820-2833.

Hall, M. B. 1998. Making nutritional sense of non-structural carbohydrates. p.108-121. In: Proceedings of the 9th Annual Florida Ruminant Nutrition Symposium. Gainesville, FL.

Harvatine, K. J. and Allen, M. S. 2006. Effects of fatty acid supplements on ruminal and total tract nutrient digestion in lactating dairy cows. Journal of Dairy Science 89:1092-1103.

Huang, Y.; Schoonmaker, J. P.; Bradford, B. J. and Beitz, D. C. 2008. Response of milk fatty acid composition to dietary supplementation of soy oil, conjugated linoleic acid, or both. Journal of Dairy Science 91:260-270.

Ingvartsen, K. L.; Dewhurst, R. J. and Friggens, N. C. 2003. On the relationship between lactational performance and health: is it yield or metabolic imbalance that cause production disease in dairy cattle: A position paper. Livestock Production Science 83:227-308.

Jenkins, T. C. 1993. Lipid metabolism in the rumen. Journal of Dairy Science 76:3851-3863.

Jenkins, T. C. and Bridges, W. C. 2007. Protection of fatty acids against ruminal biohydrogenation in cattle. Europe Journal Lipid Science Technology 109:778-789.

Jenkins, T. C.; Wallace, R. J.; Moate, P. J. and Mosley, E. E. 2008. Board-invited review: Recent advances in biohydrogenation of unsaturated fatty acids within the rumen microbial ecosystem. Journal Animal Science 86:397-412.

Kramer, J. K. G.; Fellner, V.; Dugan, M. E. R.; Sauer, F. D.; Mossoba, M. M. and Yurawecz, M. P. 1997. Evaluating acid and base catalysts in the methylation of milk and rumen fatty acids with special emphasis on conjugated dienes and total trans fatty acids. Lipids 32:1219-1228.

Mashek, D. G.; Bertics, S. J. and Grumer, R. R. 2003. Effects of intravenous infusion of triglyceride emulsions varying in lipid source on development of bovine fatty liver. Journal of Dairy Science 86:248-253.

Moallem, U.; Katz, M.; Arieli, A. and Lehrer, H. 2007. Effects of peripartum propylene glycol or fats differing in fatty acid profiles on feed intake, production, and plasma metabolites in dairy cows. Journal of Dairy Science 90:3846-3856.

Nocek, J. E. 1988. In situ and other methods to estimative ruminal protein and energy digestibility: a review. Journal of Dairy Science 71:2051-2069.

NRC - National Research Council. 2001. Nutrient requirements of dairy cattle. 7th ed. National Academy Press, Washington, DC.

Onetti, S. G. and Grummer, R. R. 2004. Response of lactating cows to three supplemental fat sources as affected by forage in the diet and stage of lactation: A meta-analysis of literature. Animal Feed Science and Technology 115:65-82.

Orellana Boero, P.; Balcells, J.; Martín-Orúe, S. M; Liang, J. B. and Guada, J. A. 2001. Excretion of purine derivates in cows: 
endogenous contribution and recovery of exogenous purine bases. Livestock Production Science 68:243-250.

Overton, T. R.; Drackley, J. K. and Ottemann-Abbamonte, C. J. 1999. Substrate utilization for hepatic gluconeogenesis is altered by increased glucose demand in ruminants. Journal of Animal Science 77:1940-1951.

Palmquist, D. L.; Weisbjerg, M. R. and Hvelplund, T. 1993. Ruminal, intestinal, and total digestibilities of nutrients in cows fed diets high in fat and undegradable protein. Journal of Dairy Science 76:1353-1364.

Palmquist, D. 2007. Biohydrogenation then and now. European Journal of Lipid Science and Technology 109:737-739.

Palmquist, D. L. and Mattos, W. R. S. 2006. Lipid metabolism. p.287-310. In: Ruminant nutrition. v.1. Berchielli, T. T.; Pires, A. V. and Oliveira, S. G., eds. Funep, Jaboticabal.

Petit, H. V. 2002. Digestion, milk production, milk composition, and blood composition of dairy cows fed whole flaxseed. Journal of Dairy Science 85:1482-1490.

Piperova, L. S.; Sampugna, J.; Teter, B. B.; Kalscheur, K. F.; Yurawecz, M. P.; Ku, Y.; Morehouse, K. M. and Erdman, R. A. 2002. Duodenal and milk trans octadecenoic acid and conjugated linoleic acid (CLA) isomers indicate that postabsorptive synthesis is the predominant source of cis-9-containing CLA in lactating dairy cows. Journal of Nutrition 132:1235-1241.

Quigley, J. D. and Drewry, J. J. 1998. Nutrient and immunity transfer from cow to calf pre- and post-calving. Journal of Dairy Science 81:2779-2790.

Rabiee, A. R.; Breinhild, K.; Scott, W.; Golder, H. M.; Block, E. and Lean, I. J. 2012. Effect of fat additions to diets of dairy cattle on milk production and components: A meta-analysis and metaregression. Journal of Dairy Science 95:3225-3247.
Skaar, T. C.; Grummer, R. R. and Dentine, M. R. 1989. Seasonal effects of prepartum and postpartum fat and niacin feeding on lactation performance and lipid metabolism. Journal of Dairy Science 72:2028-2038.

Sniffen, C. J.; O’Connor, J. D. and Van Soest, D. G. 1992. Anet carbohydrate and protein system for evaluating cattle diets: II. Carbohydrate and protein availability. Journal of Animal Science 70:3562-3577.

Ueda, K.; Ferlay, A.; Chabrot, J.; Loor, J. J.; Chilliard, Y. and Doreau, M. 2003. Effect of linseed oil supplementation on ruminal digestion in dairy cows fed diets with different forage:concentrate ratios. Journal of Dairy Science 86:3999-4007.

Verdouw, H. 1973. Enzymatic NH3-N determination: a specific method for the determination of ammonia in water and sediments. Water Research 7:1129-1136.

Van Knegsel, A. T.; van den Brand, H.; Dijkstra, J.; van Straalen, W. M.; Jorritsma, R.; Tamminga, S. and Kemp, B. 2007. Effect of glucogenic vs. lipogenic diets on energy balance, blood metabolites, and reproduction in primiparous and multiparous dairy cows in early lactation. Journal of Dairy Science 90:3397-3409.

Van Soest, P. J. 1994. Nutritional ecology of the ruminant. 2nd ed. Cornell University Press, Ithaca, NY.

Van Soest, P. J.; Robertson, J. B. and Lewis, B. A. 1991. Methods for dietary fiber, neutral detergent fiber, and nonstarch polysaccharides in relation to animal nutrition. Journal of Dairy Science 74:3583-3597.

Weiss, W. P.; Conrad, H. R. and Pierre, S. T. 1992. Theoretically-based model for predicting total digestible nutrient values of forages and concentrates. Animal Feed Science and Technology 39:95-110.

Zheng, H. C.; Liu, J. X.; Yao, J. H.; Yuan, Q.; Ye, H. W.; Ye, J. A. and $\mathrm{Wu}, \mathrm{Y}$. M. 2005. Effects of dietary sources of vegetable oils on performance of high-yielding lactating cows and conjugated linoleic acids in milk. Journal of Dairy Science 88:2037-2042. 